\title{
Review on Economic Efficiency of Maize Production in Ethiopia
}

\author{
Teka Etefa Firisa \\ Department of Agricultural Economics, Gambella University, Ethiopia
}

\begin{abstract}
Despite the fact that, agriculture remains to be the most significant sector of the Ethiopian economy, its performance has been disappointing and food production has been lagging behind population growth. Although increasing population pressure and low levels of agricultural productivity have aggravated the food insecurity situation by widening the gap between the demand for and supply of food in the country. This gap can be decreased by improving productivity either through the introduction of modern technologies or improving the efficiency of crop production. However, as the possibility to enhance production by bringing more resources into use became more and more limited, the efficiency with which the farmers use available resources has received the greatest attention. Since maize is a significant contributor to the Ethiopian economy, escalating productivity and efficiency of maize production could be taken as an important step in achieving food security. This review was aimed at assessing the levels of technical, allocative and economic efficiencies of smallholder maize producers; and to identify factors affecting the efficiency of smallholder farmers in maize production in Ethiopia. In these review factors like education, land fragmentation, livestock ownership, a frequency of extension contact, soil fertility, off/non-farm activities, sex, land owned, credit utilization and perception on agricultural policy are identified as the key determinants of the economic efficiency of maize production in Ethiopia. The frequency distribution of technical, allocative and economic efficiency levels was not fairly distributed. The maize farms were being operated in a different level of efficiency. This implies that a large number of maize farmers in Ethiopia faced inefficiency problems.
\end{abstract}

Keywords: Maize, Economic efficiency, Determinants, Ethiopia

DOI: $10.7176 / \mathrm{FSQM} / 84-04$

\section{Introduction}

\subsection{Background of the Review}

Maize (Zea mays L.) is the most widely distributed cereal crop in the world. It is one of the three leading global cereals in terms of production, with 1,016 million metric tons produced on 184 million hectares globally and the first most important crops at a global and local level followed by rice and wheat (Shiferaw et al., 2011, Njeru, 2010, FAOSTAT, 2013). The maize agri-food systems CRP focuses on (sub-) tropical maize in the low and middle-income countries that provide $64 \%$ of total maize production and where maize plays a key role in the food security and livelihoods of millions of poor farmers (Wongnaa, 2016).

Maize is produced across temperate and tropical zones and spanning all continents. It was domesticated from teosinte in Mexico some 7,000 to 10,000 years ago and rapidly extends through the Americas. It spread to the rest of the world in the $16^{\text {th }}$ through $18^{\text {th }}$ centuries. World- wide more than 400 million people, primarily in sub-Saharan Africa and Central America, maize is used as a staple food (Abdulai et al., 2018). It is comparable to that of rice or wheat in Asia, with consumption rates being the highest in ESA (Ntabakirabose, 2017; Wongnaa, 2016). Maize accounts for almost half of the calories and protein consumed in ESA and one-fifth of the calories and protein consumed in West Africa. With its multiple uses; maize is the world's most multi-purpose crop. Aside from its staple food use, it makes a significant contribution to animal feed (especially poultry) as well as bio-fuel and industrial uses (Ntabakirabose, 2017; Wongnaa, 2016).

Maize, together with rice and wheat, dominate human diets (Ignaciuk and Mason-D'Croz, 2014) and provide at least $30 \%$ of the food calories of more than 4.5 billion people in 94 developing countries. Maize alone contributes over $20 \%$ of total calories in human diets in 21 low-income countries and over $30 \%$ in 12 countries that are home to a total of more than 310 million people. Of the 22 countries in the world where maize forms the highest percentage of calorie intake in the national diet, 16 are in Africa (Nuss and Tanumihardjo, 2011).

In developed countries, $70 \%$ of maize is destined for feed, $3 \%$ consumed directly by humans and the remaining $27 \%$ uses for bio-fuels, industrial products, and seed. While in Sub-Saharan Africa, $77 \%$ of maize is using as food and only $12 \%$ serves as feed (Inuwa, 2018). Ethiopia is one of the largest grain producing countries in Africa. Though Ethiopia is a net importer of grain, it is the largest maize producer in sub-Saharan Africa. In Ethiopia, cereals are the major food crops both in terms of area coverage and volume of production (Haile et al., 2018).

The major cereal crops grown in Ethiopia are teff, wheat, barley, maize, sorghum and millet (Geda, 2014). Maize is one of the major five staple cereal crops in Ethiopia. Among crops grown in Ethiopia, maize is the most important cereal crop in terms of total production, area coverage and better availability and utilization of new production technologies (CSA, 2014). It is the highly demanded food crop in the South -western part of Ethiopia. 
High productivity and efficiency in maize production is critical to improve food security, reduce the level of poverty and achieve or maintain agricultural growth (Inuwa, 2018).

Numerous physiological, agronomic, socio-economic and managerial factors are accountable for low maize yields in Ethiopia. Poor management is more conspicuous of all the factors which decrease the productivity of smallholder maize producers (Teshome, 2005). Since managerial skill and access to resources vary from region to region, productivity also varies widely across the farming regions. Such low productivity and variation in production lead to increasing poverty and food insecurity of rural poor farm households in Ethiopia.

Agricultural production and productivity can be improved through increased use of input or enhancement in technology given some level of input/resource. The other technique of improving productivity is to enhance the efficiency of producers. In countries like Ethiopia, it is advisable to benefit from increased productivity through improving efficiency in the use of input/resource available. Therefore, assessing the factors responsible for low production and productivity of smallholder cereal crop producers in general and maize production, in particular, has dominant importance in Ethiopia.

\subsection{Objectives of the Review}

The general objective of this review is to assess the economic efficiency of maize Production in Ethiopia. The specific objectives of the review were:

$\Rightarrow$ To review the level of technical, allocative and economic efficiency of maize producing smallholder farmers in Ethiopia

- To review determinants of economic efficiency of maize producing farmers in Ethiopia.

\section{DISCUSSIONS}

\subsection{Concepts and Definitions of Production Efficiency}

Decision makers are increasingly faced with the challenges regarding reconciliation of the growing demand for agricultural output and low agricultural production in developing countries. This made them to modify development policies and strategies so that limited economic resources (land, labor, and capital) are used to produce greater output. Despite the fact that, efficiency is a significant factor for all developing countries where agriculture is the main stay of their people through its contribution is high in agricultural production stability (Bekele, 2013).

The first theoretical framework for different types of efficiency definitions and types of firms' performance analysis was introduced by the famous scholar Farrell in 1957. Farrell had extended the earlier novel works of Koopmans (1951) and Debreu (1951), who laid the foundation by introducing the concept of efficiency and the way firms' performance could be measured at the firm level in considering the input-output relationship. Efficiency in production refers to scarce resources being used in an optimal fashion (Haji, 2008). In production economics, efficiency can be understood in terms of a firm's ability to convert inputs into outputs and respond optimally to economic signals or prices (Essa, 2011). It is the act of achieving good result with little waste of effort.

The efficiency of a firm is its ability to produce the greatest amount of output possible from a fixed amount of inputs (Ahmed, 2013). It is the act of harnessing materials and human resources and coordinating these resources to achieve better management goal. The question of efficiency in resource allocation in traditional agriculture is crucial. It is widely held that efficiency is at the center of agricultural production. This is because the scope of agricultural production can be expanded and sustained by farmers through efficient use of resources (Ali, 1996; Udoh, 2000; Hailu et al., 2005). For these reasons, efficiency has remained an important subject of empirical investigation particularly in developing economies where majority of the farmers are resource-poor (Umoh, 2006; Essa, 2011).

The crucial role of efficiency in increasing agricultural output has been widely recognized by researchers (for example, Hailu et al., 2005; Ozkan et al., 2009; Ghorbani et al., 2009 among others) and policy makers alike. Because, efficiency of a farm is an indicator to its success in producing as large amount of output as possible given a set of inputs. Moreover, for determination of efficiency of a particular firm, there is a need for efficiency measurement through the production factor inputs and processes (Omonona et al., 2010). It is impossible to get identical yields with utilization of completely equal amount and quality of inputs (Essa, 2011).

There are discrepancies in the amount and values of inputs and outputs as well as profit ratios of producers (Kumbhakar and Tsionas, 2006). These discrepancies in productive efficiency of producers mainly stem from differences in technical qualifications and unfavorable exploitation of resources. The evaluation of success of the enterprise in terms of effective use of inputs which includes land, labor, seeds, chemicals, water and energy and maintenance of a thorough cost structure lies in the efficiency analysis of the process (Ozkan et al., 2009).

According to Farrell (1957), there are three types of efficiency: Those are allocative (price) efficiency, technical (physical) efficiency and economic (overall) efficiencies. The first type of efficiency is an allocative efficiency (AE), which refers to the capacity of the firm to use a set of inputs in optimal proportion with the given price and level of technology or it could be alternatively interpreted as the ability of a firm to produce a given level 
of output using cost minimizing input ratios. In welfare economics, allocative efficiency is generally considered as the benefit of the society (Palmer and Torgerson 1999).

The second type of efficiency is technical efficiency (TE), which can be defined as the performance of the given firm to obtain maximum output from a given combination of input used with the given level of technology (Farrell,1957). The given firm is technically efficient, when the combination of inputs or resources give rise to the utmost possible outcome and has no space for further enhancement of the output of the firm. Furthermore, it can be expressed as the physical relationship between inputs or resources and the final outcome or output. In a circumstance where the firm produced the same amount of output or larger than the previous production level while decreasing the use of at least one of the input in the production process, roughly indicates the existence of inefficiency in the production process.

The third type of efficiency is economic (production) efficiency, which is overall performance measure and is equal to the product of Technical Efficiency (TE) and Allocative Efficiency (AE) ( i.e. EE=TE X AE). Therefore technical and allocative efficiency are components of economic efficiency (Abdulai and Huffman, 2000; Ahmed, 2013).

An economically efficient input-output combination would be on both the frontier function and the expansion path. On the other hand, economic efficiency (EE) refers to the appropriate alternative of inputs and outputs combination according to their price relation or the ability of the firm to maximize profit by equating marginal revenue product of inputs to their respective marginal costs. According to Farrell, 1957, if a farm has attained both technically and allocatively efficient levels of production, it is economically efficient and new investment streams may be critical for any new development.

Productivity enhancement can be reached due to the improved technical, allocative and economic efficiency, technological progress or changes in the scale of production (Coelli, 1995). Efficiency, which is a central issue in production economics, is helping as a guide for allocation of resources (Farrell, 1957). In developing countries like Ethiopia, the best option for productivity improvement is increasing the efficiency of producers.

\subsection{Overview of Cobb- Douglas Production function and efficiency}

Estimation of efficiency and production functions is one of the most popular areas of research. Production is the process through which some goods and services called inputs are transformed into other goods called products or output. Production function is a systematic and mathematical expression of the relationship among various quantities of inputs or input services used in the production of a commodity and the corresponding quantities of output (Abebe, 2014). In particular, it shows the maximum level of output the firm can produce combining the existing inputs (Besanko and Braeutigam, 2005). A particular production function can be specified as: $f(x i)=$ $\max \{y i: T(x i, y i)\}$

The level of output can be enhanced in many ways. Firstly, by expanding the level of inputs used in production. This approach is called "horizontal expansion". However, increasing use of inputs is possible if either the price of output increase or the price of inputs decreases. Secondly, output can be increased by enhancing efficiency in production (Abebe, 2014). This approach is termed as "improvement approach" and requires the improvement of socio-economic, institutional and environmental constraints to enhance production using the existing inputs. Thirdly, output can be also increased by improving the technology in production. This includes use of improved techniques of production, improved seeds, modern fertilizer and chemicals. This approach is termed the "transformation approach" (Alene, 2003).

The theory explains the factors of production; resources/inputs are what are used in the production process to produce output that is, finished goods and services. The amounts of the various inputs used determine the quantity of output according to a relationship called the "production function". The basic resources or factors of production are land, labor, and capital. These factors are also frequently labeled "producer goods" to distinguish them from the goods or services purchased by consumers, which are frequently labeled as "consumer goods." All three of these are required in combination at a time to produce a commodity. The essence of a firm is to buy inputs, convert them to outputs, and sell these outputs to consumers and the firm owners seek to improve their positions by producing goods and service either those they consider most important for themselves or those that can be sold to command the goods they consider most important (Thomas and Maurice, 2013).

Cobb-Douglas production function is a particular functional form of the production function, widely used to represent the technological relationship between the amounts of two or more inputs, particularly physical capital and labor, and the amount of output that can be produced by those inputs. The term has a more restricted meaning, requiring that the function display constant returns to scale in which case $\beta=1-\alpha$. In its most standard form for production of a single good with two factors, the function is: $Y=A L^{\beta} K^{\alpha}$

\subsection{Efficiencies Level of Maize Production in Ethiopia}

Ahmed (2013) conducted study on economic efficiency of smallholder farmers in maize production. The estimated results showed that the mean level of technical, allocative and economic efficiencies was $84.87 \%, 37.47 \%$ and 
$31.62 \%$ respectively which indicates the significant inefficiency in maize production in the study area.

Bealu et al. (2013) conducted study to determine the levels of economic efficiency of smallholder maize producers and to link the observed efficiency levels to farmers' socioeconomic and institutional characteristics. The mean technical and allocative efficiencies were 72 and 70 percent, respectively while the mean economic efficiency was 53 percent.

The study results of Debebe et al. (2015), showed that the mean technical, allocative and economic efficiency score was found to be $62.3,57.1$ and $39 \%$, respectively, indicating a substantial level of inefficiency in maize production.

The study conducted by Mustefa et al. (2017), on Economic efficiency of maize production showed that the mean technical, allocative and economic efficiencies were $81.78 \%, 37.45 \%$ and $30.62 \%$ respectively. It indicated that there was significant inefficiency in maize production.

Kifle et al. (2017) shows that the mean levels of technical, allocative and economic efficiencies were $82.93 \%$, $66.03 \%$ and $54 \%$, respectively. This mean level of technical and allocative efficiencies implies that there exists possibility to increase production by $17.07 \%$ without using extra inputs and decrease cost of inputs by $33.97 \%$, respectively. The result revealed high inefficiency among maize producers.

In general, the level of technical, allocative and economic efficiencies was not the same in Ethiopia. Since, factors like demographic, socioeconomic and weather condition in the country were different from place to place. A critical factor in one place at a certain time may not necessarily be a significant factor in other places even in the same place after some time.

\subsection{Determinants of Economic efficiency of Maize Production}

The focus of this review is to provide an empirical evidence of the determinants of productivity variability or inefficiency gaps among smallholder maize farmers in Ethiopia. Having knowledge that farmers are economically inefficient might not be useful unless the sources of the inefficiency are identified. There are different factors which affect the economic efficiency of smallholder maize production in Ethiopia. However, those factors are not equally important and similar in all places at all times. A critical factor in one place at a certain time may not necessarily be a significant factor in other places even in the same place after some time. The most important constraints identified with deferent researches are the following:

According to Ahmed (2013), education was found to significantly determine allocative and economic efficiencies of farmers positively while frequency of extension contact had positive relationship with technical efficiency and it was negatively related to both allocative and economic efficiencies. Credit was also found to significantly influence technical and economic efficiencies positively and distance to market significantly affects technical efficiency negatively. The model output also indicated that soil fertility was among significant variables in determining technical efficiency of farmers. The result indicated that there is a room to increase the efficiency of maize producers.

According to Bealu et al. (2013), economic efficiency was positively and significantly affected by education, trainings, membership to cooperatives union, utilization of credit, and family size. Whereas variables such as age, distance to extension center, distance to market, livestock and off-farm income affected it negatively.

Debebe et al. (2015) indicated a substantial level of inefficiency in maize production. The result depicted that a number of family size, level of education, extension service, cooperative membership, farm size, livestock holding and use of mobile are important factors that affected technical, allocative and economic efficiency.

The study conducted by Mustefa et al. (2017), indicated that education level of the sample household was the most important factor that found to be statistically significant to affect the level of technical, allocative and economic efficiency all together. Whereas, land fragmentation and soil fertility were the major factors that affect the level of technical efficiency. Besides, land fragmentation, livestock ownership and frequency of extension contact were important factors that affect allocative efficiency of farmers. The results also further revealed that extension contact was the most important factors that found to be statistically significant to affect economic efficiency.

According to Kifle et al. (2017), age, off/non-farm activities, sex, amount of land owned and perception on agricultural policy had a significant effect on technical efficiency. Education, frequency of extension visit, perception on agricultural policy and livestock holding had significant effect on allocative efficiency while age, off/non-farm activities, sex, land owned, credit utilized and perception on agricultural policy had a significant effect on economic efficiency. The result showed that there are opportunities to increase efficiency of maize production.

Ntabakirabose (2017) indicated that improved seeds, land size, organic manure, labor and chemical fertilizer positively and significantly influenced maize productivity. Factors such as access to credit, extension services, work experience in maize production and family income were found to be statistically significant influence of the technical efficiency in the study area. However, household head age and distance to market showed a negative and significant effect on technical, allocative and economic efficiency of the maize farms. 
The study conducted by Ahmed et al. (2018), indicated that there is the potential to improve economic efficiency of maize production. This potential was relies more on allocative efficiency compared with technical efficiency. The study identified socio-economic and institutional factors are the factors that determine technical efficiency of smallholder farmers.

\section{Conclusions and Recommendations}

Agricultural sector of Ethiopia is characterized by its poor performance, while the population of the country, which to a large extent depends on agriculture, is growing at a faster rate. This necessitates looking for means to increase the productivity of smallholder farmers either by introducing new technologies or improving their efficiency levels.

Cereal crop production is the means of livelihood for millions of households in Ethiopia and is the single largest sub-sector within Ethiopia's agriculture, far exceeding all others in terms of its share in rural employment, agricultural land use, calorie intake, and contribution to national income. In Ethiopia Maize is an important crop for food security as a source of both food and income. Hence, due emphasis should be given required to enhance productivity through improvement of efficiency of resource usage in maize production. The main objective of this review is to assess the level of economic efficiency of smallholder maize producers and its determinants in Ethiopia.

The increase in the gap between population size and agricultural production requires due attention in addressing food insecurity and rural poverty in Ethiopia. Low uses of improved inputs coupled with loss of soil fertility are leading to decrease in agricultural production. Ethiopian government initiated agricultural extension programs, improved seed, and fertilizer application to improve maize productivity of smallholder farmers. Efficient production is the basis for achieving the overall food security and poverty reduction objectives particularly in major food crops producing potential areas of the country. However, farmers are discouraged to produce more because of inefficient agricultural systems and differences in efficiency of production. Generally, this review shows that there is wide variability in the efficiency level of farmers, and the majority of the farmers' attained efficiency levels of more than the average efficiency level. On the other hand, there are more farmers operating at lower efficiency level in Ethiopia.

Therefore, the results of this review give information to policy makers on how to improve the technical, allocative, and economic efficiency of smallholder farmers and optimal use of inputs/resources in production of maize in Ethiopia. The following recommendations have been drawn based on the review.

$\Rightarrow$ Review revealed that considerable variability in all efficiencies. Therefore less efficient farmers increase their efficiency level by adopting the practices of relatively efficient farmers in their area.

DIt is important to give due attention for farmers education through establishing and strengthening informal education and short term trainings by using the available human and infrastructural facilities like extension agents and Farmers Training Centers (FTCs).

$\Rightarrow$ Encouraging farmers to conserve the soil fertility improvement actions by reducing the risks and keeping their land fertile.

- Suitable and sufficient extension services should be provided for the farmers to increase their efficiencies. This could be done through appropriate ability building program to train additional development agents and to provide refreshment training for development agents.

- Financing timely and enough use of inputs through additional income generated by off/non-farm are critical. Therefore, strategies that enhance the ease use of off/non-farm employment opportunities would help to increase the timely and appropriate use of inputs for better efficiency in maize production.

$\Rightarrow$ Initiate and support gender-sensitive agricultural intervention to improve female headed farm inefficiency.

- Policy initiatives that improve the livestock holding of farmers through improved livestock breeds, forage and nutrition and health services have to be put in place.

\section{References}

Abdulai, A. and Huffman, W., 2000. Structural adjustment and economic efficiency of rice farmers in northern Ghana. Economic Development and Cultural Change, 48(3), pp.503-520.

Abdulai, S., Nkegbe, P.K. and Donkoh, S.A., 2018.Assessing the technical efficiency production in northern Ghana: The data envelopment analysis approach. Cogent Food \& vmn Agriculture , 4(1), pp.1-14.

Abebe, G.G., 2014. Off-farm income and technical efficiency of smallholder farmers in Ethiopia.

Ahmed, M.H., 2013. Economic Efficiency of Smallholder Farmers in Maize Production: The Case of Arsi Negelle District, Oromia National Regional State, Ethiopia (Doctoral dissertation, Haramaya University).

Ahmed, M.H., Tazeze, A., Mezgebo, A. and Andualem, E., 2018. Measuring maize production efficiency in the eastern Ethiopia: Stochastic frontier approach. African Journal of Science, Technology, Innovation and Development, pp.1-8.

Alene, A. D. (2003). Improved production technology and efficiency of smallholder farmers in Ethiopia: Extended parametric and non-parametric approaches to production efficiency analysis. PhD Thesis, University of Pretoria, South Africa. 
Ali, M. (1996). Quantifying the Socio-economic Determinants of Sustainable Crop Production: AAn Application to Wheat Cultivation in the Tarui of Nepal. J. Agric.Econ. 14: 45-60.

Bealu Tukela, Endrias Geta, and Tadesse Ababu 2013. Factors Affecting Economic Efficiency In Maize Production: The Case of Boricha Woreda In Sidama Zone, Southern Ethiopia. 28p.

Bekele, A.R., 2013. Technical Efficiency Variation For Smallholder Irrigated Maize Producers: A Case Study of Tibila Surface Water Irrigation Scheme (Doctoral dissertation, Mekelle University).

Besanko, D. and Braeutigam, R.R., 2005. Microeconomics. Hoboken.

Coelli T.J. 1995. Recent development in frontier modeling and efficiency measurement. Australian Journal of Agricultural Economics, 39: pp 219-245.

CSA (Central Statistical Agency) (2014). Statistical Report on population projected figures for the year 2014, Addis Ababa, Ethiopia.

Debebe, S., Haji, J., Goshu, D. and Edriss, A.K., 2015. Technical, allocative, and economic efficiency among smallholder maize farmers in Southwestern Ethiopia: Parametric approach. Journal of Development and Agricultural Economics, 7(8), pp.282-291.

Essa, C.M., 2011. Economic efficiency of smallholder major crops production in the central highlands of Ethiopia (Doctoral dissertation).

FAOSTAT (2013) http://faostat.fao.org/

Farrell M.J. 1957. The measurement of productive efficiency. Journal of Royal Statistical Society Series A., 120: 253-290.

Geda M.B. (2014). Economic Efficiency in Barely Production: The Case of Chole District, East Arsi Zone, Oromia National Regional State, Ethiopia (Doctoral dissertation, Haramaya University).

Geta, E., Bogale, A., Kassa, B. and Elias, E., 2013. Productivity and efficiency analysis of smallholder maize producers in Southern Ethiopia. Journal of Human Ecology, 41(1), pp.67-75.

Ghorbani, A., Mirmahdavi, S.A. and Rahimabadi, E. (2009). Economic efficiency of Caspian Cattle Feedlot Farms. Asian Journal of Animal Sciences 3(1): 25-32.

Haile, K., Haji, J. and Tegegne, B., 2018. Technical Efficiency of Sorghum Production: The Case of Smallholder Farmers in Konso District, Southern Ethiopia. Journal of Agriculture and Crops, 4(5), pp.50-62.

Hailu, G., Goddard, E.W. and Jeffrey, S.R., 2005, July. Measuring efficiency in fruit and vegetable marketing cooperatives with heterogeneous technologies in Canada. In American Agricultural Economics Association Annual Meeting, Providence, Rhode Island.

Haji, J., 2008. Economic efficiency and marketing performance of vegetable production in the eastern and central parts of Ethiopia (Vol. 2008, No. 17).

Ignaciuk, A., and Mason-D'Croz, D. (2014) "Modelling Adaptation to Climate Change in Agriculture", OECD Food, Agriculture and Fisheries Papers, No. 70, OECD Publishing.

Inuwa, M.M., 2018. Economic analysis and Resource Use Efficiency on Maize Production Under Sasakawa Technologies In Bauchi, Nigeria.

Kibaara, B.W., 2005. Technical efficiency in Kenyan's maize production: An application of the stochastic frontier approach (Doctoral dissertation, Colorado State University).

Kifle D. Moti J., Belaineh L. 2017. Economic efficiency of smallholder farmers in maize production in Bako Tibe district, Ethiopia. Development Country StudiesVol.7, No.2

Kifle D. Moti J., Belaineh L. 2017. Economic efficiency of smallholder farmers in maize production in Bako Tibe district, Ethiopia. Development Country StudiesVol.7, No.2.

Koopmans T.C. 1951. 'Analysis of Production as an Efficient Combination of Activities', Activity analysis of production and allocation 13: 33-37.

Koopmans T.C. 1951. 'Analysis of Production as an Efficient Combination of Activities', Activity analysis of production and allocation 13: 33-37.

Kumbhakar, S.C. and Tsionas, E.G., 2006. Estimation of stochastic frontier production functions with inputoriented technical efficiency. Journal of Econometrics, 133(1), pp.71-96.

Maddala, G.S. 2002. Introduction to Econometrics. England: John Wiley and Sons, Lt. 3rd Edition, 379 - 380.

Mustefa .Mulugeta T. and Raja K. 2017 Economic efficiency in maize production in Ilu Ababor zone, Ethiopia. Research Journal of Agriculture and Forestry Sciences Vol. 5(12), 1-8, December (201

Njeru, J. (2010). Factors Influencing Technical Efficiencies among Selected Wheat Farmers in UasinGishi District, Kenya. AERC Research Paper. Retrieved from xwceoiyi.pdf

Ntabakirabose, G., 2017. An economic analysis of the factors influencing maize productivity and efficiency in Rwanda: a case study of Gatsibo District (Doctoral dissertation).

Nuss E. T., and Tanumihardjo, S. A. (2011) "Quality Protein Maize for Africa: Closing the Protein Inadequacy Gap in Vulnerable Populations," Advances in Nutrition 2: 217-222.

Omonona, B.T., Egbetokun, O.A. and Akanbi, A.T., 2010. Farmers resource-use and technical efficiency in cowpea production in Nigeria. Economic Analysis and Policy, 40(1), p.87. 
Ozkan, B., Ceylan, R.F and Kizilay, H. (2009). A Review of Literature on Productive Efficiency in Agricultural Production. Journal of Applied Sciences Research 5(7): 796-801.

Palmer S. and D.J. Torgerson. 1999. Economic Notes: Definitions of Efficiency', BMJ (Clinical research ed.) 318(7191): 1136. Policy Research Institute, Addis Ababa, Ethiopia.

Shiferaw, B., Prasanna, B.M., Hellin, J., Bänziger, M. (2011) Crops that feed the world 6. Past successes and future challenges to the role played by maize in global food security. Food Security 3: 307-327.

Teshome, K., 2005. Technical Efficiency of Maize production: A case of smallholder farmers in Assosa Woreda. An MSc Thesis submitted to the School of Graduate Studies, Alemaya University.

Thomas, C \& Maurice, S. 2013. Managerial Economics: Foundations of Business Analysis and Strategy,667.

Udoh, E.J. (2000). Land Management Resource Use Efficiency among Farmers in South Eastern Nigeria. Unpublished Ph.D Thesis, Department of Agricultural Economics University of Ibadan Nigeria.

Umoh, G.S., 2006. Resource use efficiency in urban farming: An application of stochastic frontier production function. International Journal of Agriculture and Biology, 8(1), pp.38-44.

Wongnaa, C.A., 2016. Economic efficiency and productivity of maize farmers in Ghana (Doctoral dissertation). 